\title{
Urban dynamics An impression of Surabaya's sociolinguistic setting
}

\author{
TOM GUNNAR HOOGERVORST
}

\begin{abstract}
AbSTR ACT
This paper examines the sociolinguistic situation in the city of Surabaya, by presenting an impression of various phenomena unique to Indonesia's second largest city. A surprisingly little amount of linguistic research has heretofore been carried out on this subject, whereas it transpires from this study that enough intriguing and unique things can be found in this Southeast Asian metropolis, both among its Javanese majority as well as its Madurese and Chinese inhabitants. Due to the lack of earlier relevant publications, this research is largely based on the results of several fieldwork trips, which included the pleasant activities of watching television, interviewing people and making excursions in and around Surabaya to experience how languages are used in daily life. Additionally, concepts such as "language mixing", "slang" and "attitudes towards language" are involved and considered very significant in disentangling the role and function of language in an urban setting.

KEYWORDS

Urban social environment, Javanese language, Surabaya, linguistics, language contact, slang, and Indonesian media.
\end{abstract}

The arek Surabaya, inhabitants of the East Javanese capital Surabaya, proudly refer to their city as Kota Pahlawan, the City of Heroes. In this city, the Indonesian revolution started in 1945. In this city, the Indonesians for the first time convinced the world of the seriousness of their struggle for independence. This city, home to approximately three million inhabitants of mainly Javanese, Madurese, and Chinese origin, became Indonesia's biggest harbour and second city in size and population. Nowadays, it has developed into a metropolitan centre of economics, trade, but also culture. In relation to

TOM GUNNAR HOOGERVORST is currently starting a DPhil in Oxford as a member of the SEALINKS Programme, which aims to reconstruct prehistoric maritime trade contacts in the Indian Ocean region, for example, Indonesia, India, and East Africa. From 2002-2006 he followed the BA programme in Southeast Asian Studies at Leiden University, focussing specifically on linguistics. In addition, he worked as a translator Indonesian-Dutch and carried out research on the lexical influence of Dutch on regional languages in Indonesia. He continued his study with the MPhil programme in Asian Studies in Leiden, focussing on Austronesian linguistics. His further interests include archaeology, descriptive linguistics, literature and philology, in particular the exploration of Malay and Javanese manuscripts kept in the University Library in Leiden. 
the latter, this study elaborates on Surabaya's urban social environment from a linguistic point of view. The main research question I will address is how we should view the linguistic situation of Surabaya.

Relatively few previous publications on the subject of Surabaya's linguistic environment have hitherto been made widely available; most publications are scattered along Indonesia's universities and are not easily accessible. A lot of data used in this paper are drawn from the fieldwork I undertook in July and August 2006, July 2007, January, May, and July 2008 in Surabaya, resulting into an MPhil thesis on Surabaya's linguistic ecology (Hoogervorst 2008), supervised by Professor B. Arps and co-supervised by Dr. D. van Minde, to whom I am indebted for criticisms and corrections. The current paper is largely an adaptation of this work, though time and space restricted me from going deeply into the descriptive linguistics of vernaculars found in Surabaya. Here, I will predominantly focus on Surabaya's sociolinguistic phenomena.

This paper consists of five sections. The first addresses the main languages spoken in Surabaya. Next to the national language, Bahasa Indonesia, the city is home to several locally developed dialects and mixed languages. In the second section, I describe the usage of slang specific to Surabaya. The third section illustrates the attitude of the Indonesian government towards the regional varieties of Surabaya, especially since the so-called "decentralization" policy that took place from 1998 onwards. The fourth section offers a case study on televised language, in which I discuss the trajectories of the regional television station JTV Surabaya. Finally, the fifth section illustrates the extensiveness of the usage of regional languages in Surabaya's present-day "city-scape".

\section{The Sur abaYAN LINGUISTIC MELTING POT}

Most Surabayans are multilingual. Next to Javanese, they speak Bahasa Indonesia, Malay, or both. The local Javanese dialect, which differs from standard Javanese in phonology, lexicon and morphology, is generally subclassified as East Javanese, together with the dialects of Java's northeast coast, the area of Gresik, Java's eastern salient, the cities of Malang and Pasuruan, Mount Bromo and Banyuwangi (Hatley 1984; Kisyani-Laksono 2001; Sariono 2002; Hoogervorst 2008). There is no consensus on a standardised spelling. As I have chosen to leave the spelling of my source material unaltered and elaborate examination of Surabayan Javanese orthography falls outside the scope of this study, this paper unfortunately contains some inconsistencies in the way Surabayan Javanese words are written. In the examples I provide myself, <e> represents a mid central vowel or schwa [ə], <è> represents an open-mid front unrounded vowel $[\varepsilon]$ and $<$ é> represents a close-mid front unrounded vowel [e].

Whereas colloquial Surabayan Javanese has undergone vast lexical influence from Bahasa Indonesia (for example, see Hoogervorst 2006), the former has on its turn heavily influenced the local Malay dialect of Surabaya, described by Kartomihardjo (1981) and Hoogervorst (2008: 42-49). But let me first clarify the usage of the term "Malay", as Bahasa Indonesia is technically 
also a Malay variety; I use the term in this study to refer to the variety that existed in Surabaya long before the introduction of standardized Bahasa Indonesia in 1945. I distinguish "correct" Bahasa Indonesia spoken by the educated Surabayans from "Surabayan Malay" employed by elder and/or low educated Surabayans, especially but not exclusively those of Chinese or Arab ancestry. I find it necessary to address only the latter, although I am well aware that there is a continuum between the two.

Unlike the principalities of Yogyakarta and Solo and their surrounding areas, the Malay language has for long played an important role in Surabaya (for example, see Hutomo 1990), similar to other coastal cities such as Semarang, Cirebon, and Demak. As Surabaya became one of Java's most important harbours from the sixteenth century onwards, communication with Malay-proficient traders of various ethnicities was inevitable and a necessity. Malay, not Javanese, became the means of communication between Javanese, Chinese, and Arab Surabayans, whereas most Madurese were able to speak some Javanese. At the end of the nineteenth century, the establishment of the Malay press in Surabaya, dominated by Chinese and Eurasians, further strengthened its position at the cost of Javanese. Malay came to be the first language of many Chinese and Arab Surabayans and was used as a means of inter-ethnic communication.

After the Indonesian independence, a situation of diglossia came into being (though such a situation had probably also, to a lesser extent, existed during the colonial era) between the standard language, Bahasa Indonesia, and the local Malay vernacular. The relation between a standard language and a regional variety illustrated here is somewhat comparable to the situation in many Middle Eastern countries (for example, see Ferguson 1972), in which Modern Standard Arabic obviously fulfils the role of "high" language and the colloquial Arabic varieties are "low" languages. In the same fashion, educated Surabayans generally tend to avoid the use of Surabayan Malay in formal situations, as they are able to speak Bahasa Indonesia fluently and correctly (though their Surabayan background can still be known from their pronunciation). In informal situations, they tend to switch between Surabayan Malay and Bahasa Indonesia. Anecdotically, during my fieldwork several people mentioned that "there is no such thing as Surabayan Malay. That's just the language of the uneducated". Such views are probably common everywhere in Indonesia where a regional Malay variety occurs.

A special variety of Surabayan Malay is spoken among Surabaya's Chinese community (the same probably holds true for Surabaya's Arab community, but lack of time during my fieldwork period prevented me from learning much about their linguistic behaviour). Elsewhere I have described the Chinese Malay variety of Surabaya and characterized it as a "mixed language" (Hoogervorst 2008: 49-60). Phonologically it is similar to Surabayan Javanese, although there seems to be some Hokkien influence that I have not been able to satisfactorily describe. The lexicon is influenced by Hokkien and Dutch, and has in addition some Mandarin and "self-created" words (for example, 
lapa 'why' and yak apa 'how'; both forming "Malayised" reflexes of Surabayan Javanese words). The morphology is almost entirely from Surabayan Javanese, whereas there is a Hokkien substrate in the syntax.

Chinese Malay is still widely used among the older Chinese in Surabaya and even their children and grandchildren who received education in Bahasa Indonesia proudly use it as an in-group identity marker, albeit in a setting where they are likely not to be ridiculed. Moreover, I have witnessed several situations in which young people of Chinese descent after having met for the first time initiated a chat in Bahasa Indonesia, then gradually inserted "sinisms", and finally sustained their conversation in Chinese Malay. Whereas the Chinese in Surabaya could have switched entirely to Bahasa Indonesia, the use of Surabayan Chinese Malay seems to be a strategy to smoothen contact with others belonging to the Chinese community of Surabaya, or, rather, of East Java as a whole. I believe this especially holds true for mixed ChineseIndonesians and non-Chinese who move in Chinese circles, in other words, those whose Chinese affiliation is not obvious at first sight. Anecdotically, I have even encountered the use of Surabayan Chinese Malay on a T-shirt of the popular Surabayan brand Cak Cuk: "Kalo pigi liak-liak Surabaya, isa ndak isa bo' lupa mampiro tempate Cak Cuk Surabaya, ntik daripada sampek rumah nyesel soro" 'If you're travelling to Surabaya, you must not forget to visit Cak Cuk Surabaya, rather than regretting back home that you didn't.'

Next to the Javanese, the Chinese and the Arabs, the Madurese, especially those of West Madura, have since long made up a major part of Surabaya's population. Their presence on East Java can be traced back to the Majapahit age, although most of them consisted of slaves and prisoners in those days. One of the most important factors enabling the Madurese to dominate large parts of post-Majapahit East Java is the acknowledgement of their values as skilled mercenaries, especially by the Dutch. Military services led to migration to East Java in two ways. First, soldiers were often offered grounds on the many wastelands of East Java. Another large stream of migrants, however, settled along the coastal areas of Gresik, Pasuruan, Probolinggo, Besuki and Banyuwangi for the very reason of avoiding these compulsory services. The much softer administration in mainland East Java, together with the relative prosperity of the region, made it very attractive for Madurese to leave their infertile, over-populated home-island permanently.

According to some, the presence of the many straightforward, hardworking Madurese contributed in forming the character of the Surabayan Javanese. The Surabayans, some consultants told me, became coarse in order not to be trampled upon by the Madurese ("diinjak sama Madura"). A part from such pleasant speculations, it is evident that the Madurese language influenced the lexicon of Surabayan Javanese. Frequently used Surabayan Javanese words of Madurese origin are buru 'just', carok 'to fight', congok 'stupid', pena 'you (polite)', polè 'moreover' and torkop 'to hit s.o. with the fist in the face'. Other commonalities, of which it is less clear which language influenced the other, are ambèk 'with', cik 'very', gibeng 'to hit s.o. in the face', kathik 'with', kopok 
'deaf', mari 'finished' and tepak' exactly'. Finally, the Madurese in Surabaya, as well as other parts of East Java, speak a typical form of Javanese with lexical and grammatical imposition from Madurese (Soegianto 1981; Budiarsih 1988; Suhendra 1996; Hoogervorst 2008: 61-68).

\section{THE SLANG OF A CITY}

Non-Surabayan Javanese frequently state that the Surabayan dialect is coarse (kasar), whereas Surabayans themselves prefer epithets like blaka suta, blakblakan, or blak kotang, all meaning 'frankly speaking'. The above discrepancy is, I believe, based partly on the "powerful", Madurese-influenced intonation of Surabayan Javanese, and partly on the use of speech levels (unggah-ungguh or undha usuk), which are characteristic for Central Javanese dialects but less refined in, among others, Surabaya. In addition, the Surabayan dialect has a notoriously vast scale of swearwords (pisuhan). In this section, I will particularly concentrate on Surabaya's abundance of informal or non-standard expressions (slang).

Surabayan slang consists for a great deal of Basa Walikan, a reversed language originally from the neighbouring city of Malang but now found in many other parts of East Java. The use of Basa Walikan conveys equality and homogeneity among the interlocutors of one specific social group, either school children, pickpockets or prostitutes. The system of reversal is lexical, not syntactical, thus making it relatively easy to learn if one knows the pertinent rule or rules. Besides reversing words, Basa Walikan has three other strategies of encoding speech (see also Sudarwati 1987): (1) Creating acronyms, such as korak 'criminal' ( $\leftarrow$ kotoran rakyat 'the scum of the people'), and sintharo 'mad' ( $\leftarrow$ sinthing separo 'half crazy'); (2) Providing new meanings to existing words: ngentup 'to sting' $\rightarrow$ 'to have sexual intercourse', mlorot 'to fall' $\rightarrow$ 'to have sexual intercourse', kèpang 'horse made of woven bambu' $\rightarrow$ 'motorcycle', biasa 'habitual' $\rightarrow$ asaib (the reversed form) 'prostitute'; and (3) "Making up" new, previously not existing words. Words of the latter group that I have come across include halabu 'to ignore', bangkok 'pretty', sarik 'pretty', dhepos 'to have sexual intercourse', sikim 'knife', nileb 'to steal', koleng 'drunk', ngatèsi 'to deceive', ndèsit 'rural', amprin 'lover', naskim 'to eat', kuyès 'to lie', hayik' to have sexual intercourse', ngoyok 'to rob', tarhèt 'to take', gomblèk 'girl', wanyok 'person', wanyik 'kid', idrèk 'work', and ojir 'money'. None of these forms are easily traced back etymologically, although one could make an educated guess that the latter three are somehow derived from archaic Javanese kenya [kəлo] 'girl', kardi 'work', and arja [ardzo] 'money'.

From an argot only known by a closed community, from the 1970s onwards Basa Walikan gradually became generally known among Malang people, becoming a significant part of their speech and identity. Consultants underline that Basa Walikan is very frequently used in Malang by especially male interlocutors from 12-50 years. It is used for practical communication, but also to emphasize a feeling of solidarity towards Malang and especially its inhabitants. Wherever two arek Malang meet, the usage of Basa Walikan as 
an instrument of their common identity is inevitable. Hence, epithets such as "secret language" or "code language" have become somewhat contradictive, as Basa Walikan is now often used in the presence of others, regardless of their capability to understand what is being said. Such a change seems to have occurred too within other "secret languages" of the region, for instance Indonesian gay language (Boellstorff 2007: 114-138). Nevertheless, in other parts of East Java, such as Surabaya, Mojokerto, and the eastern salient, Basa Walikan is still used predominantly as a secret language, as not everyone over there is as proficient as the arek Malang. In Surabaya, Basa Walikan can often still be used as a means to gossip about people (ngrasani), as the chance that the object of the conversation will immediately and accurately understand everything is still limited. Illustratively, of women can be said that they are sinam 'pretty' ( $\leftarrow$ manis), tahès 'chubby' ( $\leftarrow$ sehat 'healthy'), ngetem 'pregnant' $(\leftarrow$ meteng), uya 'pretty' $(\leftarrow a y u)$, or komès 'callipygian' $(\leftarrow$ semok).

One thing one needs to be aware of, is that Basa Walikan is very dynamic and therefore to a certain extent able to remain a cryptolect. In other words, one has to be an insider to know which words are popular and which words are not. Sudarwati (1987: 41), who offers a pioneering piece of scholarship on this cryptolect, notes that members of the various gangs of Malang, among which Marabunta (Spanish marabunta 'fire ant'), Seksi Yongen (Dutch sexy jongen 'sexy boy'), and Embong Brantas 'Brantas road', used their own specific words. Therefore, one needs to be a group member to correctly use Basa Walikan. For 'to eat', 'to go home', 'I', 'you', 'not', 'friend', and 'many', most interlocutors use Indonesian reversed words instead of Javanese: makan $\rightarrow$ nakam, pulang $\rightarrow$ ngalup, saya $\rightarrow$ ayas, kamu $\rightarrow$ ukam, tidak $\sim$ tak $\rightarrow$ kadit $\sim$ kat, kawan $\rightarrow$ nawak, banyak $\rightarrow$ kanyab.

Next to Basa Walikan, which is now more widely understood by Surabayans albeit speakers from Malang remain most fluent, Surabaya has another type of slang restricted to its gay community. The data used on Surabayan gay slang in this paper are taken from Oetomo (1990). Remarkably, several Dutch words are used: yongen 'boy' ( $\leftarrow$ jongen), kranekh 'handsome' $(\leftarrow$ kranig), baleces 'testicles' ( $\leftarrow$ balletjes), sepèlen 'to have sexual intercourse' $(\leftarrow$ spelen 'to play'), wil 'to feel attracted to so.' ( $\leftarrow$ willen 'to want'), èke 'I' ( $\leftarrow i k k e)$, and yé 'you' ( $\leftarrow j i j)$. Further, this language has three processes of encoding words. 1) Taking the first three letters and adding si-: sikon 'friend' $(\leftarrow k a n c a$ [kont5o]), silan 'man' ( $\leftarrow$ lanang), sipul 'police' ( $\leftarrow$ pulisi). Javanese phonotactic rules apply (notably the dispreference of word final affricates and retroflex consonants): siwèd 'woman' ( $\leftarrow$ wedok), sibod 'spouse' ( $\leftarrow$ bojo), siged 'big' $(\leftarrow$ gedhe). 2) Replacing the penultimate vowel with $[\varepsilon]$ and the syllable rime with [on]: bèncong 'gay' ( $\leftarrow$ banci), berbèlong 'with hair' ( $\leftarrow$ Indonesian berbulu), perèmpèong 'woman' ( $\leftarrow$ Indonesian perempuan). 3) Replacing the penultimate vowel with $[\varepsilon]$ and the syllable rime with [ $\varepsilon s]$ : sèngès 'nine' ( $\leftarrow$ sanga), mèès 'to have sexual intercourse' ( $\leftarrow$ Indonesian main 'to play'), klèwès 'ejaculation' ( $\leftarrow$ Indonesian keluar $\sim$ kluwar 'to go out'). The latter two processes are also found in Jakartan gay slang (Van der Meij 1983; Boellstorff 2007). The popular 
East Javanese slang word èbès 'father' is probably an adaptation of the third type, derived from $a b a$ (Arabic $a b \bar{u}$ _أبـ 'father').

Consultants informed me that a Surabayan youth language developed from the 1990s onwards, taking the first three letters of a word and adding $<1>$ plus the first vowel of the word: lomob 'car' $(\leftarrow$ mobil), leken 'transport' $(\leftarrow$ Indonesian kendaraan), labal 'prostitute' ( $\leftarrow$ balon), lustup 'stupid', lodol 'Gang Dolly'. Many Surabayans I consulted, however, found this language highly affected (gawe-gawean) or nonsense (ngomong taek). When asked about the newest (June 2008) slang, they mentioned bocor 'out of your mind', masyuk! 'okay!', and tambah sipaé 'really?', derived from Indonesian bocor 'leaky', Indonesian masuk 'to enter' and Surabayan Javanese tambah sip ae 'it keeps getting better'. Other specific Surabayan slang words I have encountered are bekut 'marijuana', lonthong 'silly', tarpo 'stupid', kacrok 'to loose', kaspo 'to deceive', aongat 'to have an erection', lakon 'man' (compare Indonesian laki), gombès 'deceiver' (compare Indonesian gombal), banclèr 'homosexual' (compare Indonesian banci), honger 'to eat' (compare Dutch honger 'hungry'), ngopral 'to drink coffee' (compare Surabayan Javanese ngopi), and dèspèk 'low' (compare Indonesian pendek).

\section{DECENTR ALIZATION, REGIONALISM, AND MEDIA}

In less than ten years after the abrupt end of Soeharto's New Order in 1998 and the political reformation (reformasi) that took place subsequently, we see a completely changed linguistic landscape in Indonesia. In this section, based on an unpublished paper (Hoogervorst 2007) presented at the occasion of the Intensive Programme South East Asia hosted by the Institut National des Langues et Civilisations Orientales in 2007 and, subsequently, on the last section of the MPhil thesis of this author (Hoogervorst 2008: 69-81), I will attempt to describe what changes took place in Surabaya and how they relate to other parts of Indonesia.

From 1836 onwards, the city of Surabaya can be called home to a variety of newspapers, first exclusively in Dutch, but later also in Malay, Javanese, Madurese, and Arabic (Soemijatno 1994: 6). Also, the first two magazines completely in Javanese, Panjebar Semangat, that started as early as the 1930s, and Jaya Baya, with its first edition published in 1945, were and are published in Surabaya. Further, the city possesses two local television stations, TVRI Jawa Timur and JTV Surabaya. The Surabayan vernacular of Javanese, however, was hardly used in the printed and televised media during and prior to the New Order. Like many other regional vernaculars, Surabayan Javanese was originally only a means of oral communication, including transactions at markets, religious sermons, and traditional art performances.

In the colonial time, the dialect was rarely used in a written context. Communication between the Dutch and the ordinary Javanese, if any, was carried out in Malay, which was for neither of the two groups a language of particularly high proficiency. Javanese in service of the colonial government learned Dutch to communicate with their superiors. The Surabayan Javanese 
vernacular was, in the terms of Ferguson (1972), a "low" language, in the sense of being used exclusively for informal, in-group communication. I have come across very few sources of written Surabayan Javanese from this period. The relatively small group of educated Javanese were taught the Solo-based literary Javanese, which can also be found occasionally in early Surabayan newspapers (for example, see Soemijatno 1994), although the majority of the newspapers in Java were in Dutch. As far as I know, only Swara Oemoem and Soesoeloeh Oemoem had sections in Surabayan Javanese. In 1935, the Javanese author Besoet published one of the first widely available short stories in Surabayan Javanese: "Insaf [...]" 'Be aware [...]', published in the just established magazine Panjebar Semangat (Hutomo 1991: 16).

During the Japanese occupation, the usage of Dutch, as well as English, was banned and downplayed as the language of the enemy (bahasa mungsuh). Due to the absence of Dutch, other languages, such as Malay, were provided more room to function as a means of communication. Although there were some Japanese attempts to learn something about regional languages, such as Javanese and Madurese, this did not result into any notable change in the status of Surabayan Javanese or regional languages in general. In this period, attempts were also made to implement Japanese as a means of communication, a strategy that became famous as "suppressing the nation by suppressing their language" (tindas bangsa, tindas bahasa). The Japanese language was taught in most elementary schools and, as various aged people recalled, even some place names that the Japanese found difficult to pronounce were changed, for example, Mojokerto into Moyokeruto, Krian into Kuriyan, Gempolkerep into Gemporokerupo, etcetera, something that obviously did not get the slightest support from the Javanese.

After the Indonesian independence, Bahasa Indonesia was promoted as the only official language, as the Sumpah Pemuda dictates: Satu Tanah, Satu Bangsa, Satu Bahasa, 'One Nation, One People, One Language'. As a result, Bahasa Indonesia became the pre-eminent language of the government, whereas the local languages were hardly ever used for official announcements. Newspapers and magazines were almost exclusively in Bahasa Indonesia. The only examples known to me of written Surabayan Javanese in this period are certain sections in the newspaper Suara Indonesia Minggu ("Paitun") and in the Javanese magazines Jaya Baya ("Surabayan") and Panjebar Semangat ("Apa tumon"). In Panjebar Semangat, the occasional rubric Obrolane cak Wan was entirely in the Surabayan dialect, whereas Jaya Baya sporadically placed Surabayan Javanese short stories (cerkak), of which those written by M. Sholeh, a pseudonym of the well-known author Suparto Brata, were very popular. Unlike Central Javanese literature, the nature of these Surabayan Javanese texts was generally quite similar to actual speech. Another option was to mix provincialisms into standard Javanese discourse, as was often done by Sasmito Esmiet. This author - originally from the village Kasiyan near Mojokerto, but more often identified with his second home Banyuwangi - wrote several cerkak and novels in standard Javanese. Further, the author and university teacher Sri 
Setyowati alias Trinil also made use of Surabayan idiom and in a later stage began to write prose and poetry entirely in Surabayan Javanese. Other, less renowned authors attested to use Surabayan Javanese are A.S. Tamsir, Tantri Asikin, Yunani, and Poerwadi Atmodihardjo (Wibisono 1992: 11).

Besides these few rubrics in the written media, further usage of Surabayan Javanese during the New Order was restricted to occasional art performances on local radio or television. In several types of performing arts, such as ludrug, wayang cek dong and srimulatan, the language was either entirely Surabayan Javanese or mixed with archaic Javanese speech styles. Cassette tapes of these performances became widely available. However, throughout the New Order, Javanese in the media remained intertwined with a kind of traditionalism. Most performances were musically enlisted with gamelan and the actors wore traditional Javanese or Madurese clothes, whereas western clothes and music were associated with Bahasa Indonesia, the language of modernism and public discourse.

The reformasi yielded a political inclination called "decentralization" (desentralisasi), in which political power and also religious and cultural institutional matters previously centralized in Jakarta were gradually delegated or reallocated from the nation's capital (ibukota) to its peripheries (daerah). As a result, the taboo on using local languages (bahasa daerah), in education, but also in the media, was permanently broken. In many Indonesian provinces, decentralization led to an upswing of regional languages such as Javanese, Sundanese, Madurese, Minangkabau, Buginese, and Acehnese, but also foreign languages, in particular English and Mandarin Chinese. The television station Surya Citra Televisi (SCTV) was the first to broadcast the news in Bahasa Indonesia, English, and Mandarin. Not only languages, but also dialects, especially Javanese dialects, were increasingly used in the media. In this aspect, the city of Surabaya had once again a pioneering function.

Since May 2001, the Surabayan Language Centre (Balai Bahasa Surabaya) started to focus predominantly on local research projects (Trinil 2001). At the same time, important developments took place in the district of Banyuwangi, where the usage of the local Javanese vernacular (Using) became extremely popular. Local Banyuwangi songs in the kendhang kempul style were widely available on VCD all over East Java. Alongside Using music, Using literature was also revived. In 2002, the Cultural Centre of East Java (Taman Budaya Jawa Timur) published several works of poetry in the Using, Madurese, East Javanese and Eastern Central Javanese vernaculars under the title Antologi puisi; Sastra campursari 'Antology of Poetry; Mixed literature'. I hold the opinion that the abovementioned changes within the linguistic ecology of Using asserted their influence on Surabaya. In 2004, it was time for the first publication of poetry completely in Surabayan Javanese, as Sri Setyowati alias Trinil finished her anthology called Donga kembang Waru 'Prayer of the Waru flower'. One year later, she wrote the first novel completely in Surabayan Javanese, Sarunge Jagung 'maize sheath'. Understandably, after this success more and more authors became inspired to write cerkak in the Surabayan dialect. 
Nowadays, the Surabayan Javanese dialect is represented in almost all the relatively new media of the 21st century. A medium that has become a very important carriage of Surabayan Javanese discourse is the Internet. On the various East Javanese mailing lists (milis), Yahoo groups, and weblogs, the arek Surabaya, among which many who live outside of their birth region and long to use their native tongue, communicate through written Surabayan Javanese. Very popular were, and are, the Humor Suroboyoan, online Surabayan Javanese jokes (banyolan) told by Budhi Santoso. In addition, several stands situated on the Surabayan sidewalks offer a diversity of pirated (bajakan) CD's and VCD's varying from traditional East Javanese music styles such as tayub, campursari, dangdut koplo, and Islamic-based qasidah, to pop and rap music. Examples of the latter include Jangan Asem, a popular local pop band, and Blackstar, a Surabayan rap group. As an illustration, below I provide some selected prose of one of the songs by Blackstar, Juventus vs. MU (the translation is mine):

Ya pancen kadhang-kadhang awak dhewe gak sak dalan Tapi iku tak anggep ya mek salah pengertian Padha karo bal-balan, iya isok salah umpan Makane awak dhewe ya ojok sampek tukaran Kadhang aku ngguyu lek ndelok arek pacaran Tukaran kaplok-kaplokan ya sampek jejek-jejekan Ngono ya jarene engkok sampek pelaminan Paling ya mek dituroni trus ditinggal klayapan
Though we have our fair share of differences I just see them as misunderstandings Like in football, mistakes occur easily So we shouldn't allow ourselves to fight Sometimes I laugh, looking at couples Smacking each other, even kicking each other People say that later when they're married He'll just sleep with her and then runs away

\section{THE POWER OF A CITY TELEVISION STATION}

JTV Surabaya, one of the two local East Javanese television channels, with the slogan Satus persen Jawa Timur 'hundred percent East Java', followed the examples of SCTV and on 7 July 2003 launched the first Indonesian television program completely hosted in bahasa daerah: Pojok Kampung. Although mainly a translation from the existing news program Pojok Pitu, the show became a tremendous success. It can and must also be seen as a breakthrough, in the sense that the presenters did not wear the traditional Javanese clothes formerly associated with the usage of Javanese on television. Several months later, JTV Surabaya launched Pojok Madura, the Madurese equivalent. Recently, more and more broadcasts on JTV Surabaya are completely in Surabayan Javanese. It is highly expectable that local news broadcasts in other Indonesian provinces will copy the idea, just as television shows in Javanese dialects can nowadays (end 2008) be seen in Yogyakarta and Banyumas. Whereas the popularity of Using music and literature influenced the linguistic ecology of Surabaya, the "defolklorization" of regional languages in the media, invented in Surabaya, asserted its influence on a variety of other Indonesian linguistic ecologies.

Let us now enjoy an ordinary day in front of JTV Surabayan television. The usual morning begins with the news program Pojok Isuk, broadcasted in Bahasa Indonesia. After that, it is time for a very rare and innovative phenomenon in Indonesian television history: Beskop Suroboyoan. Like most Indonesian television channels, movies from China, India or the United States are broadcasted around 10 A.M. Uniquely, the movies on JTV Surabaya are 
in Surabayan Javanese! Bollywood movies from India, for instance, are, with exception of the songs, completely dubbed into the Surabayan Javanese vernacular. Obviously, this might go at cost of the storyline, as certain idioms in Hindi cannot easily be translated into other languages. The creators of the so-called India Suroboyoan, however, chose to impose Surabayan Javanese idioms as much as possible. The Hindi-song a character is humming, then, is replaced by the Surabayan song Rek, ayo rek, and at a wedding scene, the mother-in-law shouts enthusiastically: E, mantene teka, e bukakna klasa! 'The bride has arrived, untie the woven mats', a phrase also used in a traditional Javanese song. A group of critics of these broadcasts is found among the Chinese in East Java, who are not happy with the often clumsy translations of their favourite Chinese movies in Cino Suroboyoan, the Chinese program segment of Beskop Suroboyoan. All in all, these dubbed movies (filem dhabingan) are not extremely popular among the inhabitants of East Java; they have been subject of disagreement since the concept of dubbing movies into Surabayan Javanese was first brought up by the famous Surabayan author Suparto Brata (Arps and Van Heeren 2006: 316). Or, as a passer-by once put it when he saw me watching a dubbed movie: "Indhia kok cara Surabayaan!" 'Indians speaking Surabayan!?', in which the accusing intonation of his utterance revealed a profound contempt.

After the movies, it is time for a news update. The same messages we saw on Pojok Pitu are now uttered in basa alus. As a compromise for the people who find the language of Pojok Kampung too coarse, especially the non-Surabayan East Javanese, in the broadcast called Pojok Kulonan, the same messages are brought in a rather Solo-based speech style. As usual in Indonesia, the broadcasts are approximately every 10 minutes interrupted by commercials. Some of them are in Surabayan Javanese. Then, it is time for Kuis $R T / R W$, a quiz held almost entirely in the dialect of Surabaya. After that, we see today's news again, this time in Madurese, in a broadcast of Pojok Madura. In the evening, most broadcasts are in strongly local-coloured Bahasa Indonesia, often with code-switching to Surabayan Javanese. Examples of such shows, often filled with typical Surabayan jokes, are Kabarwani and Kok Hin, Opo maneh. In the latter, host presenter Sholihin Hidayat alias Kok Hin together with his three hostesses, who each represent one of the three biggest ethnic groups in Surabaya, that is the Javanese, the Madurese, and the Chinese, go through the latest news in East Java. The show is brought in a humorous way, in which the element of language has the function of teasingly stereotyping the characteristic parlance of the Chinese and the Madurese. After that, usually a Surabayan Javanese soap opera (sinetron) is broadcasted.

Finally, around 9 P.M., it is time for today's summon of "Surabayaness": Pojok Kampung. The compound pojok kampung refers to a sentry post in a traditional Javanese village, or, rather, a street corner in an urban Surabayan neighbourhood. In any case, it is a location where people meet, talk, and laugh together. One of the most important things to bring people together is a shared language. We first hear the presenter Ning Festine speak her famous 
introductory line "Dhulur-dhulur, yok apa kabare?" 'Siblings, how are you?', then we see the exact same messages we have seen on Pojok Pitu, Pojok Kulonan, and Pojok Madura. Additionally, we are offered a piece of education in the Surabayan language, as Cak Albaroyo - an acronym for Ahli Bahasa Suroboyo 'the expert on the Surabayan language'; an imaginary character played by comedian Eko Londo - reads and explains the "word of the day" in the segment Kamus Suroboyoan 'Surabayan dictionary'. Interestingly, during Pojok Kampung, even the messages in the message box at the bottom of the screen are in Surabayan Javanese:

Peno lek gak kepingin ketinggalan berita'ne seputar Suroboyo ambek Jawa Timur sing nggae boso Suroboyoan kirimen SMS ketik: REG POJOK kirimen nang: 9333 (Gae kabeh Operator) taripe murah: Rp 500,-/sms.

If you do not want to miss out on any actuality reports from around Surabaya and East Java in the Surabayan language, send an SMS with the text: REG POJOK, to: 9333 (for all operators), for a cheap rate: Rp 500,-/sms.

The programmers of Pojok Kampung have repopularized or even "invented" several words, finding their way nowadays into the daily usage of Surabayan Javanese. Examples of these are pistul gombyok 'fringed gun' or gagang uyuh 'urine stalk' for 'penis', empal brewok 'slice of whiskered meat' for 'vagina', and laki, kenthu, and nggeble for 'sexual intercourse'. For example, the phrase tuku empal brewok nang lokalisasi 'to buy whiskered meat at the prostitution complex' in fact means 'to have sexual intercourse with a prostitute'. Additionally, the terminology of the credits at the end of the show consists of Surabayan Javanese neologisms, such as sulih bahasa, sing nyoting, sing ngronce gambar, sing noto suoro, and sing noto klambi, for respectively 'language advisor', 'camera man', 'editor', 'sound man', and 'clothing advisor'. Despite these inventive attempts of "language building", it often becomes painfully clear that the used Surabayan Javanese is a direct translation from the original script in Bahasa Indonesia in Pojok Pitu. Surabayans also criticize the accent of the presenters, which, although following most phonological rules of Surabayan speech, misses the right intonation and still leans too much on Bahasa Indonesia.

The show Pojok Kampung is rated BO (Bimbingan Orangtua 'Parental Advisory'), which for a great deal has to do with the language used. As could be expected, the broadcasting of the show yielded a fierce polemic, in which the main argument against the show was its complete absence of deferential speech forms, even regarding respected members of society. The show is often known to employ vulgar epithets instead. Rather than ngendika 'to say', the word nyocot is used, whereas the neutral form would be ngomong. In the same manner, the words mbadhog, nyekek, and nguntal are used instead of mangan 'to eat' or its krama inggil form dhahar. These forms are unacceptably coarse for non-Surabayan Javanese and a part of the Surabayan population itself, especially those with access to literary standard Javanese. Thereupon, Pojok Kampung has triggered various language riots one would not normally 
associate with Indonesia. On one occasion, the Pojok Kampung crew saw themselves summoned by the Regional Indonesian Broadcasting Committee (Komite Penyiaran Indonesia Daerah, KPID) to the Province of East Java's Bureau for Information and Communication (Dinas Infokom) to clarify their choice of such vulgar epithets (Arps and Van Heeren 2006: 314). On several other occasions, they were confronted with protests from angry mobs. Once, JTV Surabaya was forced to officially apologise after announcing the decease of a respected Islamic leader (kyai) by using the word matek instead of tilar or pejah (Kisyani-Lakono 2004: 9-10). Other regularly expressed annoyances my consultants experienced are the choice of the epithets mbidheg for 'to claim ignorance', bajingan for 'thief', lonthe or balon for 'prostitute', gendhakan or kelonan for 'to make love', preketek for 'to pretend', and ngencuk for 'having sexual intercourse' or even 'to rape'.

However, unlike most non-Surabayan Javanese, especially those from Central Java, a majority of the autochthonous Surabayans does not find the discourse of Pojok Kampung too coarse. They proudly describe their dialect as spontaneous and egalitarian (spontan dan egaliter), whereas Central Javanese is regarded feudalistic (feodalistis). Some of the sentences are even found quite humorous, like "Gak slamet temen koen, nek nyolong nok omahe kaji Slamet" 'You are definitely not safe, if you steal at the house of hajji Slamet' (Kisyani-Lakono 2004: 6). Also, the concluding remarks often trigger a laugh, as the female presenter involves the audience, making fun of them, as is seen in the example "Dherek, mandhor kawat clanane kolor/Mangane kuwat tandhang gaene kendhor /Ya koyok pena iku cak" 'Siblings, a cable supervisor wears shorts / He knows how to eat, but not how to work / Just like you, man' (KisyaniLakono 2004: 6).

\section{A TOWN FULL OF SUR ABAYAN JAVANESE}

In the preceding section, I have argued that a lot of new developments concerning the usage of Surabayan Javanese are mediated through television. Finally, we will focus on other usage of the dialect. After a decade of desentralisasi, one can see Surabayan Javanese being used anywhere on the street. To illustrate the extensiveness of its usage in and around the city of Surabaya, I will describe a journey one can take, as I have often done, from the provincial town (kota kabupaten) of Mojokerto to the metropolitan province capital of Surabaya.

We start our journey from the alun-alun. The first example of Surabayan Javanese we hear from the Al Fattah mosque, where a sermon is held in this vernacular. Going southwards, we enter the Jalan Mojopahit, the most important road in town. There, we see on a big shop sign the text "Idenya sopo rek? Idenya Cosmos" 'Whose idea is it? It's Cosmos' idea', belonging to the Cosmos shop, a company specialized in electric home appliances. This is a "Surabayanization" of their original slogan launched in August 2002: "Idenya siapa? Idenya Cosmos". A similar example is a poster from Telkomsel, one of Indonesia's biggest telecommunication companies: "Ngomong sak karepmu mek rp. 2000 sedinoan" 'Chat all you want for only 2000 rupiah a day', originally 
"Ngobrol semaumu cuma rp. 2000 seharian".

As in many other parts of Java, the small shops have Javanese rather than Indonesian names, whereas the majority of the somewhat bigger shops often carry flashy English or English-based names. We come across podo marem 'all content', moro dadi 'ready at arrival', ono roso '[we] have taste', and warung ndeso 'village stall'. After two left turns, we enter the Jalan Hayam Wuruk. There, less friendly messages await us, as several walls have become victims of graffiti painting (pengeboman). One wall tells the story of "Dibom muslik cino maling" 'Bomb those polytheist Chinese thieves', another one states "PSMP koyok kontol cok!" ‘PSMP (Persatuan Sepakbola Mojokerto Putra 'Mojokerto soccer club for boys') sucks, man!'. A more harmonious text can be seen as we drive several miles to the south: "Wika FM: Radione arek Mojokerto" 'Wika FM: The radio for Mojokertoans'. As we stop before a traffic light, a street vendor offers us today's Radar Mojokerto, the local edition of the popular newspaper Jawa Pos. On the front page, we see in bold letters: "Lapindo ngomong thok!" 'Lapindo does nothing but talk!'. PT Lapindo Brantas is the oil and gas exploration held responsible for the Lusi (lumpur Sidoarjo 'Sidoarjo mudflow'), an eruption of gas and mud that started on 28 May 2006 in the city of Porong. The subsequent devastating mudflow could hitherto (December 2008) not be stopped. That the East Javanese have lost their remaining faith in this company is confirmed yet again when we hear the first lines of the local song Lumpur Lapindo 'the "Lapindo" mudflow' on the radio: "Aku gak isok turu / mikir sedhulurku / sing urip rekasa / onok kutha Porong" 'I cannot sleep / thinking of my siblings / that have a hard time / in the city of Porong'.

A few miles outside the city, we come across a place that is commonly referred to as Rolak Songo; a Dutch-built construction forming the largest floodgate in East Java. Again, the shops on the roadsides have Javanese names, such as bolo dewe 'our own people', podo rukun 'all in harmony', sumber urip 'the spring of life', and warung suroboyo 'Surabayan stall'. The many pickup trucks on the road have similar names: tombo kepingin 'cure for desire', pokok e melo 'if only you'd join', ngreken ae nggak 'don't count on it', budal mole 'leaving homewards', londo ireng 'dark European', ojo nyocot 'watch your mouth', pokok e maler 'the main thing is to go on' and, sarcastically, lumpur lapindo 'the "Lapindo" mudflow'! Besides giving their vehicles names, many East Javanese also decorate them with stickers, like "Jaga jarak cok!" 'Maintain distance, man!', "Aku wonge oke" 'I'm all right', and "Usahane wees pol! Tapi hasile sek nol?" 'Maximal endeavour, but still zero achievement?'.

As the radio plays an East Javanese pop song by Mus Mulyadi, and our car approaches the city of Surabaya, we see the Surabayan dialect regularly used on street banners (spanduk, from Dutch spandoek). In the village of Mondongan, our attention is drawn to the local elections: "Woro-woro. Pemilihan kepala desa. Ojo lali!" 'Announcement. Elections for village head. Don't forget it!', whereas in Waru, we are warned against the dangers of drugs: "Wesss... wesss... nggawe narkoba donyamu bakal ancur!" ‘Don't... don't... using drugs will destroy your world!'. On the way to Surabaya, we see that Surabayan Javanese is 
intensely used for political causes. Four out of five candidate duos for this year's governorship (2008) used a Surabayan Javanese slogan: "Lek iso dadi gubernur lapo dadi wakil" 'If we're able to become governor, why go for deputy?' (Khofifah Indar Parawansa - Mudjiono), "Ayo dulur, ndandani jatim bersama" 'C'mon siblings, let's improve East Java together' (Sutjipto - Ridwan Hisjam), "H. Achmady: gubernure wong cilik" 'H. Achmady: the governor of the common people' (Achmady - Suhartono), "Elingo brengose, makmur bersama wong cilik" 'Remember those moustaches, prosperous together with the common people' (Soekarwo - Saifullah Yusuf), whereas only the team Soenarjo - Ali Maschan Musa chose a rather dull Indonesian slogan: "Bekerja keras dan mengabdi" 'Work hard and serve'. A few miles before entering Surabaya, we note on a road sign the well-known Javanese phrase - popularized by Indonesia's first president Soekarno - "holobis kuntul baris" "“holobis", herons in line'. This phrase refers to the collective execution of labour and is regarded by many as one of the main principles of Javaneseness. Right behind this wonderful example of wisdom, we see a commercial sign from the automotive company Aspira, stating: "apa ae merk motor kon lek pinter gawe aspira" 'Whatever your brand of motorcycle is, if you're smart you'll use Aspira'.

In Surabaya, we come across the usage of a third language, as approximately one fourth of its inhabitants are of Madurese origin. Thus, in Surabaya we can see trilingual signs, such as "Jangan buang sampah sembarangan!; Ojo" mbuwak sampah sembarangan po'o rek!; Je' muang bu rombuh den beden!" 'Don't throw garbage anywhere you feel like it!'. It is, I think, only a matter of time before the fourth big language in Surabaya, Mandarin, is given its rightful place on the above sign. In the last few years, the local government has made an increasing use of (especially local) Javanese alongside Bahasa Indonesia as a means of communication towards the people, so that we might come across (electronic) traffic signs such as "Pengen lancar? Antri..o....reek" '[Do you] want to drive smoothly? Form a line, man', and "Jalan lagi di remet-remet, patuhi peraturan yen pengin slamet" "The road is being levelled; obey the rules if you want to be safe'. Furthermore, Surabayan Javanese can be used for advisory purposes, as can be seen from the signs "Suroboyoku resik lan ijo" 'My clean and green Surabaya' and "Suwun cak! Suroboyo tambah nyaman" 'Thanks man! Surabaya is now more pleasant'.

Along the roadside, many warung sell Surabayan souvenirs. One can buy a T-shirt with the text "Ciri khase arek Suroboyo" "The typical features of a Surabayan", underneath dictating: "Jujur Agresif Nekad Cekatan Ulet Kreatif" 'Honest Aggressive Determined Adroit Tough Creative' which, when read from the top to the bottom, shows the swearword jancuk 'fuck'. Where Yogyakarta has its famous brand Dagadu and Bali has Joger, in Surabaya shirts of the brand Cak Cuk are increasingly popular. The stand across the street sells t-shirts with the text Bajul ijo 'Green crocodile', referring to Surabaya's soccer team Persebaya. Along the way back we see big commercial signs, for Hartono Electronics: "Gak usah lirak-lirik rek" 'You don't have to gaze, man' and Telkomsel: "Gak mbulet itungane" 'An untangled calculation'. After an 
afternoon well-spent in its devastating heat, we say goodbye to Surabaya for the time being and take the toll road (jalan tol) back, but not before we have been greeted by a hospitable "Lek sampeyan kuat munggah, monggo lewat" 'If you have the power to ride, please come along', which turns out to be a commercial for a new Isuzu pick-up truck.

\section{CONCLUSION}

In modern Indonesia, with a vital standard language spoken and understood by more than 200 million people, the usage of Javanese seems paradoxical; on one side the Javanese try to hold on to their traditions, on the other side many want to be as modern as possible. I have argued that the Surabayans for a long time played a pioneering role in combining these two extremes: the first magazines entirely in Javanese were and are published in this city, the first non-traditional television broadcast entirely in Javanese dialect was invented in this city, and the use of Javanese on traffic signs and campaign posters started in this city. Whereas the use of Javanese has been "folklorized" throughout the New Order, Surabayans found the way to combine local speech and culture with global developments.

In this paper I have attempted to provide an impression of Surabaya's sociolinguistic setting. The majority of its inhabitant are fluent in Bahasa Indonesia as well as the local Javanese and Malay dialect, the latter forming a continuum with Bahasa Indonesia. In addition, immigrants of Chinese and Madurese ancestry have created their own, mixed vernaculars with unique lexical and grammatical features. Somewhat more restricted is the use of specific slang found in various distinct settings, including schools, the underworld and the gay community. None of these colloquial, informal varieties were appreciated or encouraged by the Indonesian government prior to 1998, but as a result of the "decentralization" policy this situation changed drastically. Next to literature, music and web pages in Surabaya's regional vernaculars, the local television station JTV Surabaya played a decisive role in promoting Surabayan Javanese and, to a lesser extent, Madurese and local Malay varieties, as legitimate means of communication, to the extent that we can now see these vernaculars being used everywhere within Surabaya's urban setting.

\section{REFERENCES}

Arps, Bernard and Katinka van Heeren. 2006. “Ghosthunting and vulgar news; Popular realities on recent Indonesian television", in: HenkSchulte Nordholt (ed.), Indonesian Transitions, pp. 289-325. Yogyakarta: Pustaka Pelajar.

Boellstorff, Thomas David. 2007. A coincidence of desires; Anthropology, queer studies, Indonesia. Durham and London: Duke University Press.

Budiarsih, Ririn. 1988. “Pengaruh kosakata Bahasa Madura terhadap Bahasa Jawa pada siswa SMP negeri I kecamatan Kalisat kabupaten daerah tingkat II Jember". Thesis, Faculty of Arts, Universitity of Jember. 
Ferguson, C.A. 1972. "Diglossia", in: Pier Paolo Giglioli (ed.), Language and social context: selected readings, pp. 232-251. London: Penguin Books.

Hatley, Ron. 1984. "Mapping cultural regions of Java", in: Ron Hatley, Jim Schiller, Anton Lucas, Barbara Martin-Schiller, Other Javas; Away from the kraton, pp. 1-32. Melbourne: Monash University.

Hoogervorst, Tom. 2006. "Percampuran bahasa di Surabaya; Pengaruh Bahasa Indonesia terhadap Bahasa Jawa Suroboyoan". BA thesis, Leiden University.

Hoogervorst, Tom. 2007. "Decentralizing speech in East Java”. Unpublished paper, INALCO, Paris.

Hoogervorst, Tom. 2008. “Basa Jawa Surabayaan; Describing Surabaya's linguistic ecology". M.Phil thesis, Leiden University.

Hutomo, Suripan Sadi. 1990. "Peranan bahasa dan sastra Melayu akhir abad XIX di Surabaya", Basis; Madjalah bulanan untuk soal-soal kebudajaan umum XXXIX: 406-419.

Hutomo, Suripan Sadi. 1991. "Dialek Bahasa Jawa sebagai pengungkap kesusasteraan Jawa". Paper, Kongres Bahasa Jawa, Semarang, 15-20 July.

Kartomihardjo, Soeseno. 1981. Ethnography of communicative codes in East Java. Canberra: Department of Linguistics, Australian National University. (Pacific Linguistics D39).

Kisyani-Laksono. 2001. "Identifikasi dialek dan subdialek Bahasa Jawa di Jawa Timur bagian utara dan Blambangan". Paper, Kongres Bahasa Jawa III, Yogyakarta, 15-20 July.

Kisyani-Laksono. 2004. "Pojok Kampung: berita berbahasa Jawa yang naik daun". Paper, Seminar Internasional Bahasa dan Budaya Austronesia, Denpasar, 19-21 August.

Oetomo, Dede. 1990. "Bahasa rahasia waria dan gay diSurabaya", in: Muhadjir and Basuki Suhardi (eds), Bilingualisme dan variasi bahasa, pp. 199-208. Depok: Fakultas Sastra Universitas Indonesia.

Sariono, Agus. 2002. Bahasa dan Sastra Using; Ragam dan alternatif kajian. Jember: Tapal Kuda.

Soegianto. 1981. "Interferensi Bahasa Madura terhadap bahasa-bahasa Jawa di daerah Pantai Utara Jawa Timur". Paper, Forum Linguistik, Jakarta, 26-28 October.

[Soemijatno. 1994.] Pers Jatim; Dari masa ke masa. [Surabaya: Serikat Penerbit Suratkabar Jawa Timur].

Sudarwati. 1987. "Ragam bahasa remaja di kotamadya Malang". Thesis, Faculty of Arts, University of Jember.

Suhendra. 1996. "Interferensi gramatikal Bahasa Madura terhadap pemakaian Bahasa Jawa dalam interferensi penjual dan pembeli di pasar Tanjung Kotif Jember (suatu tinjauan morfologis)". Thesis, Faculty of Arts, University of Jember.

Trinil. 2001. "Balai Bahasa Surabaya gawe bengkel sastra Jawa”, Jaya Baya 7: 9.

Van der Meij, Th.C. 1983. "Enige aspecten van de geheimtaal in Jakarta". Thesis, Leiden University. 
Wibisono, Bambang. [1992]. "Laporan penelitian; Dialek Jawa Timuran dalam kesusastraan Jawa modern". Thesis, Faculty of Arts, University of Jember. 